\title{
Pengaruh Pembiayaan Mudharabah, Musyarakah Dan Ijarah Terhadap Profitabilitas Bank Umum Syariah Di Indonesia
}

\author{
Devi Sri Hartati ${ }^{1 *}$, Dailibas ${ }^{2)}$, Isro'iyatul Mubarokah ${ }^{3)}$ \\ 1,2,3Fakultas Ekonomi - Akuntansi, Universitas Singaperbangsa Karawang \\ *Email korespondensi: devisrih1610@gmail.com
}

This study aims to determine the effect of mudharabah, musyarakan and ijarah financing jointly or partially on profitability at Islamic Commercial Banks in Indonesia for the 2015-2019 Period. The data used are the financial statements of Bank BCA Syariah and Bank Mandiri Syariah which provide quarterly financial reports. The research method used in this research is quantitative descriptive method. This study used the Multiple Linear Regression model, using four classical assumption tests, namely normality test, multicollinearity test, autocorrelation test and heteroscedasticity test. The results of this study indicate that partially mudharabah has no effect on profitability. Musyarakah partially has a positive and significant effect on profitability. Partially ijarah has a positive and significant effect on profitability. Simultaneously mudharabah, musyarakah and ijarah have a significant effect on return on asset (ROA).

Keywords: Mudharabah, Musyarakah, Ijarah, Profitability (ROA)

Saran sitasi: Hartati, D. S., Dailibas., \& Mubarokah, I. (2021). Pengaruh Pembiayaan Mudharabah, Musyarakah Dan Ijarah Terhadap Profitabilitas Bank Umum Syariah Di Indonesia. Jurnal Ilmiah Ekonomi Islam, 7(01), 235240. doi: http://dx.doi.org/10.29040/jiei.v7i1.1836

DOI: http://dx.doi.org/10.29040/jiei.v7i1.1836

\section{PENDAHULUAN}

Perbankan di Dunia sedang mengalami perkembangan yang sangat pesat begitu pula di Indonesia. Perbankan akan mendorong perekonomian nasional, dalam dunia perbankan selain bank konvensional, terdapat juga bank syariah yang banyak berkembang di berbagai negara seperti di Indonesia. Pada bank konvensional penentuan harga selalu didasarkan dengan bunga, sedangkan pada bank syariah didasarkan pada konsep Al-Quran dan AsSunnah yaitu kerja sama antara kedua belah pihak dalam skema bagi hasil baik untung maupun rugi. Tujuan utama Bank Syariah adalah sebagai upaya kaum muslim untuk mendasari segenap aspek kehidupan ekonominya berdasarkan Al-Quran dan As-Sunnah.

Menurut Undang-Undang Nomor 21 tahun 2008 tentang Perbankan Syariah dalam pasal 1 menjelaskan bahwa Bank Konvensional adalah bank yang menjalankan kegiatan usahanya secara konvensional berdasarkan prosedur yang ditetapkan oleh negara, sedangkan Bank Syariah adalah Bank yang menjalakan kegiatan usahannya berdasarkan prinsip syariah atau prinsip hokum islam dan menurut jenisnya terdiri atas Bank Umum Syariah dan Bank Pembiayaan Rakyat Syariah. Faktor-faktor yang meningkatkan profitabilitas bank syariah adalah pembiayaan. Jeni pembiayaan bank syariah sebagai penentu tingkat profitabilitas yang digunakan dalam penelitian ini adalah mudharabah, musyarakah dan ijarah (Cut Faradilla, 2017).

Pembiayaan Mudharabah menurut Wiroso (2011:326) adalah perjanjian kerjasama untuk mencari keuntungan antara modal dan kerja / usaha. Perjanjian tersebut bisa jadi terjadi antara deposan (investment account) sebagai penyedia dana (pemegang rekening investasi) dan bank syariah sendiri sebagai mudharib. Bank syariah menjelaskan keinginannya untuk menerima dana investasi dari sejumlah nasabah, pembagian keuntungan disetujui antara kedua belah pihak sedangkan kerugian ditanggung oleh penyedia dana, asalkan tidak terjadi kesalahan, atau pelanggaran syariah yang telah ditetapkan, atau tidak terjadi kelalaian di pihak bank 


\section{Jurnal Ilmiah Ekonomi Islam, 7(01), 2021, 236}

syariah. Kontrak mudharabah dapat juga diadakan antara bank syariah sebagai pemberi modal atas namanya sendiri atau khusus atas nama deposan, pengusaha, para pengrajin lainnya termasuk petani, pedagang, dan sebagainya. Mudharabah berbeda dengan spekulasi yang berunsur kepada perjudian (gambling) dalam pembelian dan transaksi penjualan.

Pembiayaan Musyarakah menurut Wiroso (2011:395) adalah suatu bentuk kemitraan di antara bank Islam dan para nasabahnya, dimana masingmasing bagian akan memberiakn sumbangsihnya kepada modal tersebut dengan tingkat yang setara atau berbeda-beda untuk mendirikan suatu proyek baru atau sebagian dalam proyek yang telah ada, dimana masing-masing mereka akan menjadi pemegang saham modal atas dasar tetap atau menurun dan akan memperoleh bagian keuntungan sebagaiman mestinya. Akan tetapi, kerugian akan dibagi bersama secara sebanding sesuai dengan sumbangsih modal dan apabila tidak ditentukan lain, tidak akan ditetapkan lain.

Sedangkan pembiayaan ijarah menurut Wiroso (2011:455) adalah akad pemindahan hak guna (manfaat) atas suatu asset dalam waktu tertentu dengan pembayaran sewa (ijarah) tanpa diikuti dengan pemindahan kepemilikan asset itu sendiri. Sewa yang dimaksud adalah sewa operasi (operating lease).

Salah satu indikator untuk menilai kinerja keuangan suatu bank adalah melihat tingkat profitabilitasnya. Kinerja keuangan adalah salah satu indikator keberhasilan atas kesehatan suatu bank. Profitabiltas dipakai untuk memperlihatkan seberapa besar laba atau keuntungan yang diperoleh dari kinerja suatu bank yang mempengaruhi catatan atas laporan keungan yang harus sesuai standar akuntansi keuangan. Profitabilitas adalah rasio yang menunjukkan kemampuan perusahaan dalam menghasilkan laba selama periode tertentu yang diukur dengan kesuksesan dan kemampuan perusahaan menggunakan aktivanya secara produktif (Munawir, 2004). Mengukur besarnya profitabilitas suatu perbankan salah satunya dengan menggunakan ukuran Return on Assets (ROA).

Return On Assets (ROA) Menurut Kasmir (2012:201) adalah rasio yang menunjukan hasil (return) atas jumlah aktiva yang digunakan dalam perusahaan. Dengan kata lain ROA dapat di definisikan sebagai rasio yang menunjukkan sebarapa banyak laba bersih yng bisa diperoleh dari seluruh kekayaan yang dimiliki perusahaan.
Penelitian yang dilakukan oleh Cut Faradilla (2017) hasil penelitian menunjukan bahwa secara simultan murabahah, istishna, ijarah, mudharabah dan musyarakahberpengaruh terhadap profitabilitas pada Bank Umum Syariah di Indonesia. Penelitian ini juga di perkuat oleh A. Haris Romdhoni (2018) hasil penelitian menunjukan bahwa secara simultan pembiayaan mudharabah, musyarakah dan ijarah berpengaruh terhadap profitabilitas (ROA) Pada Bank Muamalat Indonesia tahun 2010-2017.

Berdasarkan uraian diatas maka penulis tertarik untuk maelakukan penelitian dengan judul: "Pengaruh Pembiayaan Mudharabah, Musyarakah Dan Ijarah Terhadap Profitabilitas Bank Umum Syariah Di Indonesia". Sesuai dengan latar belakang diatas, penulis merumuskan masalah sebagai berikut:

a. Bagaimana pengaruh mudharabah terhadap profitabilitas pada Bank Umum Syariah di Indonesia tahun 2015-2019?

b. Bagaimana pengaruh musyarakah terhadap profitabilitas pada Bank Umum Syariah di Indonesia tahun 2015-2019?

c. Bagaimana pengaruh ijarah terhadap profitabilitas pada Bank Umum Syariah di Indonesia tahun 2015-2019?

d. Bagaimana pengaruh mudharabah, musyarakah dan ijarah terhadap profitabilitas pada Bank Umum Syariah di Indonesia tahun 2015-2019?

\section{Tujuan Penelitian}

Tujuan dari penelitian ini adalah sebagai berikut:

a. Untuk mengetahui, menganalisis dan mendeskripsikan pengaruh mudharabah terhadap profitabilitas pada Bank Umum Syariah di Indonesia tahun 2015-2019?

b. Untuk mengetahui, menganalisis dan mendeskripsikan pengaruh musyarakah terhadap profitabilitas pada Bank Umum Syariah di Indonesia tahun 2015-2019?

c. Untuk mengetahui, menganalisis dan mendeskripsikan pengaruh ijarah terhadap profitabilitas pada Bank Umum Syariah di Indonesia tahun 2015-2019?

d. Untuk mengetahui, menganalisis dan mendeskripsikan pengaruh mudharabah, musyarakah dan ijarah terhadap profitabilitas pada Bank Umum Syariah di Indonesia tahun 2015-2019? 


\section{METODE PENELITIAN}

Penelitian ini menggunakan metode penelitian deskriptif kuantitatif, "Metode deskriptif adalah penelitian yang dilakukan uantuk mengetahui keberadaan variable mandiri, baik hanya pada satu variable atau lebih (variable yang berdiri sendiri) tanpa membuat perbandingan dan mencari hubungan variable itu dengan variable yang lain. Sedangkan data kuantatif dalah data penelituan berupa angka - angka, yang akan dianalisis menggunakan data statistic yang telah diterapkan". Sugiyono (2017:35).

Penelitian ini dilakukan pada Bank BCA Syariah dan Bank Mandiri Syariah tahun 2015-2019. Data laporan keuangan triwulan yang telah dipublikasikan oleh bank tersebut. Penelitian ini menggunakan data sekunder, maka penelitian ini menggunakan teknik Analisis Deskriptif, Uji Asumsi Klasik, Regresi Linier Berganda Dan Pengujian Hipotesis.

\section{HASIL DAN PEMBAHASAN}

\subsection{Hasil Penelitian}

Analisi Deskriptif

Tabel 1.1. Descriptive Statistics

\begin{tabular}{|l|r|r|r|r|r|}
\hline & $\mathrm{N}$ & Min & Max & Mean & $\begin{array}{c}\text { Std. } \\
\text { Deviation }\end{array}$ \\
\hline Mudharabah & 40 & 1.73 & 895.60 & $1.5484 \mathrm{E} 2$ & 189.62082 \\
Musyarakah & 40 & 1.02 & 26.77 & 8.6232 & 8.32009 \\
Ijarah & 40 & 1.04 & 986.10 & $3.0076 \mathrm{E} 2$ & 323.53867 \\
ROA & 40 & .42 & 1.69 & .9458 & .30849 \\
Valid N & 40 & & & & \\
(listwise) & & & & & \\
\hline
\end{tabular}

Pada tabel diatas menunjukn jumlh data yang diteliti berjumlah 40 data, Mudharabah menghasilkan nilai maximum 895.60 dan nilai minimum sebesar 1.73, mean variable mudharabah 1.5484 dan standar deviai sebesar 189.62082. Musyarakah menghasilkan nilai maximum 26.77 dan nilai minimum sebesar 1.02, mean sebesar 8.6232 dan standar deviasi sebesar 8.32009. Ijarah menghasilkan nilai maximum sebesar 986.10 dan nilai minimum sebesar 1.04, mean sebesar 3.0076 dan standar deviasi 323.53867. sedangkan ROA menghasilkan nilai miximum 1.69 dan nilai minimum sebesar 0.42 . mean sebesar 0.9458 dan standar deviasi sebesar 0.30849 .

\section{Uji Asumsi Klsik}

Uji Normalitas

Tabel 1.2. Uji Normalitas

One-Sample Kolmogorov-Smirnov Test

\begin{tabular}{|ll|r|}
\hline & & $\begin{array}{c}\text { Unstandardized } \\
\text { Residual }\end{array}$ \\
\hline $\mathrm{N}$ & Mean & 40 \\
Normal & Std. Deviation & .26339426 \\
Parameters & & .102 \\
Most Extreme & Absolute & .102 \\
Differences & Positive & -.091 \\
& Negative & .646 \\
Kolmogorov-Smirnov Z & .798 \\
Asymp. Sig. (2-tailed) &
\end{tabular}

a. Test distribution is Normal.

Dari tabel diatas dapat dilihat jika nilai signifikan sebesar 0.798 yang mana nilai ini lebih besar dari 0,05 maka dapat disimpulkan bahwa data pada penelitian ini telah berdistribusi normal.

\section{Uji Multikolinieritas}

Uji multikolinieritas merupakan uji syarat kedua setelah normalitas. Untuk melihat apakah diantara variable independen tidak terdapat korelasi maka dapat dilihat nilai Tolerance dan VIF.

Tabel 1.3. Uji Multikolinieritas

\begin{tabular}{|c|c|c|c|c|c|c|c|c|}
\hline \multicolumn{9}{|c|}{ Coefficients $^{\mathbf{a}}$} \\
\hline & & \multicolumn{2}{|c|}{$\begin{array}{c}\text { Unstandardized } \\
\text { Coefficients }\end{array}$} & $\begin{array}{l}\text { Standardized } \\
\text { Coefficients }\end{array}$ & $\mathrm{t}$ & Sig. & Collinearity & tistics \\
\hline \multicolumn{2}{|c|}{ Model } & $\mathrm{B}$ & Std. Error & Beta & & & Tolerance & VIF \\
\hline \multirow[t]{4}{*}{1} & (Constant) & .586 & .111 & & 5.284 & .000 & & \\
\hline & Mudharabah & .000 & .000 & .254 & 1.450 & .156 & .661 & 1.512 \\
\hline & Musyarakah & .019 & .007 & .523 & 2.921 & .006 & .631 & 1.585 \\
\hline & Ijarah & .000 & .000 & .449 & 2.715 & .010 & .740 & 1.351 \\
\hline
\end{tabular}

a. Dependent Variable: ROA 
Dari tabel diatas menunjukkan bahwa hubungan antara kedua variable bebas menunjukkan nilai tolerance tidak menunjukkan multikolinieritas, karena nilai tolerance mudharabah, musyarakah dan ijarah > dari 0,10. Demikian juga dengan nili VIF menunjukkan tidak terjadi multikolinieritas, karena nilai VIF mudharabah, musyarakah dan ijarah $<10$.

\section{Uji Heteroskedastisitas}

Tabel 1.4. Uji Heteroskedastisitas seatterplet

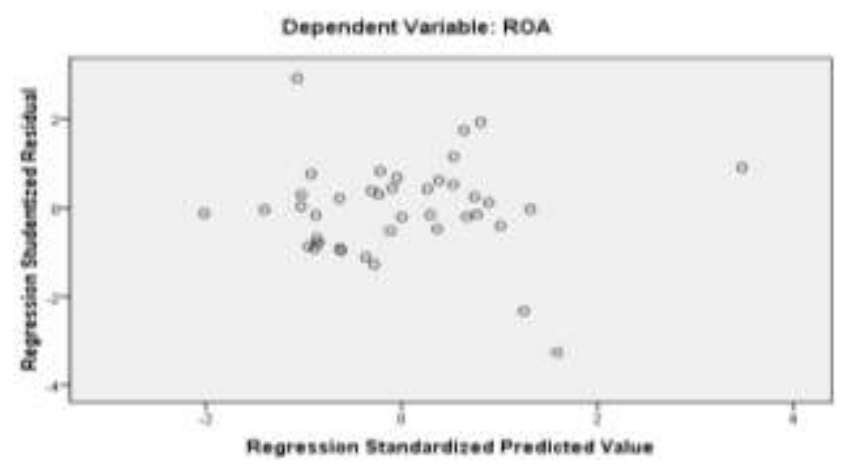

Berdasarkan output Scatterplots diatas di ketahui bahwa :

1. Titik-titik data penyebar diatas dan di bawah atau di sekitar angka 0 .

2. Titik-titik tidak mengumpul hanya di atas atau dibawah saja.

3. Penyebaran titik-titik data tidak membentuk pola bergelombang melebar kemudian menyempit dan melebar kembali.

4. Penyebaran titik-titik data tidak berpola.

Dengan demikian dapat disimpulkan bahwa tidak terjadi masalah heteroskedastisitas, sehingga model regresi yang baik dan ideal dapat terpenuhi.

\section{Uji Autokorelasi}

Tabel 1.5. Uji

Autokorelasi

Model Summary ${ }^{b}$

\begin{tabular}{|l|l|r|r|r|r|}
\hline $\begin{array}{l}\text { Mod } \\
\text { el }\end{array}$ & $\mathrm{R}$ & $\begin{array}{c}\mathrm{R} \\
\text { Square }\end{array}$ & $\begin{array}{r}\text { Adjusted } \\
\text { R Square }\end{array}$ & $\begin{array}{c}\text { Std. Error } \\
\text { of the } \\
\text { Estimate }\end{array}$ & $\begin{array}{l}\text { Durbin- } \\
\text { Watson }\end{array}$ \\
\hline 1 & $.521^{\mathrm{a}}$ & .271 & .210 & .27415 & 1.763 \\
\hline
\end{tabular}

a. Predictors: (Constant), Ijarah,

Mudharabah, Musyarakah

b. Dependent Variable: ROA
Berdasarkan tabel diatas diketahui bahwa nilai durbin watson sebesar 1,763 yang artinya 1,658< $1,763<2.341$. perbandingan nilai menggunakan nilai signifikan 5\%, jumlah sampel 40 (n). dan jumlah variable independent $3(\mathrm{k}=3)$, maka di tabel durbin watsonkn didapat nilai du sebesar 1,658. Nilai durbin watson 1,763 lebih besar dari batas atas (du) 1,658 dan kurang dari 4-du $(4-1,658)=2,341$, maka dapat disimpulkan bahwa tidak terdapat autokorelasi pada data yang digunakan pada penelitian ini.

\section{Regresi Linier Berganda}

Tabel 1.6. Regresi Linier Berganda Coefficients $^{\mathrm{a}}$

\begin{tabular}{|l|r|r|r|r|r|}
\hline \multirow{2}{*}{ Model } & \multicolumn{2}{|c|}{$\begin{array}{c}\text { Unstandardiz } \\
\text { ed } \\
\text { Coefficients }\end{array}$} & $\begin{array}{c}\text { Standard } \\
\text { ized } \\
\text { Coeffici } \\
\text { ents }\end{array}$ & & \\
\cline { 2 - 4 } & B & \multicolumn{1}{c|}{$\begin{array}{c}\text { Std. } \\
\text { Error }\end{array}$} & Beta & t & Sig. \\
\hline 1 (Constant) & .586 & .111 & & 5.284 & .000 \\
Mudharabah & .000 & .000 & .254 & 1.450 & .156 \\
Musyarakah & .019 & .007 & .523 & 2.921 & .006 \\
Ijarah & .000 & .000 & .449 & 2.715 & .010 \\
\hline
\end{tabular}

a. Dependent

Variable: ROA

Regresi adalah hubungan fungsional yang terjadi antara satu variabel dependen dengan variabel independen, agar dapat diketahui nilai duga rata-rata variabel dependen atas pengaruh variabel independen tersebut. Penelitian ini menggunakan model regresi linier berganda. Variabel-variabel penelitian ini dapat dinyatakan dalam model sebagai berikut :

$$
\mathrm{Y}=\alpha+\beta 1 \mathrm{X} 1+\beta 2 \mathrm{X} 2+\beta 3 \mathrm{X} 3+\mathrm{e}
$$

Dimana:

$\mathrm{Y}=\mathrm{ROA}$

$\mathrm{a}=$ Konstanta

$\mathrm{X} 1=$ Mudharabah

$\mathrm{X} 2=$ Musyarakah

$\mathrm{X} 3=$ Ijarah

e $\quad=$ Random error atau variabel gangguan

$\beta 1, \beta 2, \beta 3=$ Koefisien regresi masing-masing variabel independen. 


\section{Uji t}

Berdasarkan hasil pengujian tabel 1.6 variabel mudharabah memiliki angka sig $0,156>0,05$ sehingga mudharabah (X1) tidak mempengaruhi profitabilitas (Y). Sedangkan musyarakah memiliki angka sig 0,006 $<0,05$ sehingga musyarakah (X2) mempengaruhi profitabilitas (Y). Dan ijarah memiliki angka sig $0,010<0,05$ sehingga ijarah (X3) berpengaruh terhadap profitabilitas $(\mathrm{Y})$.

\begin{tabular}{|c|c|c|c|c|c|}
\hline \multicolumn{6}{|c|}{$\begin{array}{c}\text { Tabel 1.7. Uji F } \\
\text { ANOVA }^{\mathbf{b}}\end{array}$} \\
\hline Model & $\begin{array}{l}\text { Sum of } \\
\text { Squares }\end{array}$ & Df & $\begin{array}{c}\text { Mean } \\
\text { Square }\end{array}$ & F & Sig. \\
\hline 1Regression & 1.006 & 3 & .335 & 4.461 & $.009^{\circ}$ \\
\hline Residual & 2.706 & 36 & .075 & & \\
\hline Total & 3.712 & 39 & & & \\
\hline
\end{tabular}

a. Predictors: (Constant), Ijarah,

Mudharabah, Musyarakah

b. Dependent Variable:

ROA

Berdasarkan pada tabel diatas diperoleh angka sig $0,009<0,05$ membuktikan bahwa secara bersamaan mudharabah, musyarakah dan ijarah mempengaruhi profitabilitas (ROA) secara signifikan.

\section{Koefisien Determinasi}

Tabel 1.8. Koefisien Determinasi Model Summary ${ }^{b}$

\begin{tabular}{|l|c|r|r|r|r|}
\hline $\begin{array}{l}\text { Mod } \\
\mathrm{el}\end{array}$ & $\mathrm{R}$ & $\begin{array}{c}\mathrm{R} \\
\text { Square }\end{array}$ & $\begin{array}{c}\text { Adjusted } \\
\text { R Square }\end{array}$ & $\begin{array}{c}\text { Std. Error } \\
\text { of the } \\
\text { Estimate }\end{array}$ & $\begin{array}{l}\text { Durbin- } \\
\text { Watson }\end{array}$ \\
\hline 1 & $.521^{\mathrm{a}}$ & .271 & .210 & .27415 & 1.763 \\
\hline
\end{tabular}

a. Predictors: (Constant), Ijarah,

Mudharabah, Musyarakah

b. Dependent Variable: ROA

Berdasarkan pada tabel diatas Mudharabah (X1), Musyarakah (X2), dan Ijarah (X3) selama tahun 20152019 memberikan kontribusi sebesar 27,9\% terhadap profitabilitas (Y), adapun kontribusi yang disebabkan oleh variable lain sebesar $72,1 \%$.

\subsection{Pembahasan}

Pengaruh Pembiayaan Mudharabah terhadap Profitabilitas (ROA)

Berdasarkan hasil uji $\mathrm{t}$ terhadap variable mudharabah memperoleh nilai signifikan 0,156 > 0,05 maka H1 ditolak, hasil penelitian ini menunjukkan bahwa variable mudharabah tidak berpengaruh terhadap profitabilitas (ROA) laporan keuangan triwulan Bank BCA Syariah dan Bank Mandiri Syariah tahun 2015-2019. Hasil dari penelitian konsisten dengan penelitian yang dilakukan oleh Afkar (2017) yang menyatakan bahwa pembiayaan mudharabah tidak berpengaruh terhadap profitabilitas Perbankan Syariah di Indonesia.

\section{Pengaruh Pembiayaan Musyarakah terhadap Profitabilitas (ROA)}

Berdasarkan hasil uji $\mathrm{t}$ terhadap variable musyarakah memperoleh nilai signifikan 0,006 <0,05 maka $\mathrm{H} 2$ diterima, hasil penelitian ini menunjukkan bahwa variable musyarakah berpengaruh positif dan signifika terhadap profitabilitas (ROA) laporan keuangan triwulan Bank BCA Syariah dan Bank Mandiri Syariah tahun 2015-2019. Hasil dari penelitian konsisten dengan penelitian yang dilakukan oleh Ditha Nada Pratama (2017) yang menyatakan bahwa pembiayaa musyarakah berpengaruh positif dan signifikan terhadap profitabilitas Bank Muamalat Indonesia.

\section{Pengaruh Ijarah terhadap Profitabilitas (ROA)}

Berdasarkan hasil uji $\mathrm{t}$ terhadap variable ijarah memperoleh nilai signifikan $0,010<0,05$ maka H3 diterima, hasil penelitian ini menunjukkan bahwa variable ijarah berpengaruh positif dan signifika terhadap profitabilitas (ROA) laporan keuangan triwulan Bank BCA Syariah dan Bank Mandiri Syariah tahun 2015-2019. Hasil dari penelitian konsisten dengan penelitian yang dilakukan oleh Purnama Putra (2018) yang menyatakan bahwa sewa ijarah berpengaruh positif dan signifikan terhadap profitabilitas pada Bank Umum Syariah yang terdaftar di Bank Indonesia.

\section{Pengaruh Pembiayaan Mudharabah, Musyarakah dan Ijarah terhadap Profitabilitas (ROA) \\ Berdasarkan pada tabel uji $\mathrm{F}$ diperoleh angka sig $0,009<0,05$ membuktikan bahwa secara bersamaan mudharabah, musyarakah dan ijarah berpengaruh secara signifikan terhadap profitabilitas (ROA).}




\section{KESIMPULAN}

Berdasarkan hasil penelitian maka dapat disimpulkan bahwa secara parsial mudharabah tidak terdapat pengaruh terhadap profitabilitas (ROA). Secara parsial musyarakah terdapat pengaruh positif dan signifikan terhadap profitabilitas (ROA). Secara parsial ijarah terdapat pengaruh positif dan signifikan terhadap profitabilitas (ROA). Adapun pembiayaan mudharabah, musyarakah dan ijarah secara bersamasama berpengaruh terhadap profitabilitas (ROA) Bank BCA Syariah dan Bank Mandiri Syariah tahun 20152019.

\section{UCAPAN TERIMAKASIH}

Dalam penyusunan artikel ini, penulis mendapat dukungan, bantuan, do'a dan motivasi dari berbagai pihak secara langsung maupun tidak langsung sehingga penyusunan artikel ini dapat terselesaikan. Untuk itu pada kesempatan ini dengan segala kerendahan hati penulis ingin menyampaikan banyak terima kasih kepada semua pihak yang terlibat.

\section{DAFTAR PUSTAKA}

Afkar, T. (2017). Influence Analysis of Mudharabah Financing and Qardh Financing to The Profitability of Islamic Banking in Indonesia. Asian Journal of Innovation and Entrepreneurship, 2(03), 340-351.

Faradilla, C. Arfan, M. Shabri, M. (2017). Pengaruh Pembiayaan Murabahah, Istishna, Ijarah, Mudharabah Dan Musyarakah Terhadap Profitabilitas Bank Umum Syariah Di Indonesia. Jurnal Magister Akuntansi. Vol. 6 No. 3.
Kasmir. (2012). Analisis Laporan Keuangan. Jakarta. Rajagrafindo Persada.

Munawir. (2004). Analisis Laporan Keuangan. Yogyakarta. Liberty.

Pratama, N.D. Martika, D.L. Rahmawati, T. (2017). Pengaruh Pembiayaan Mudharabah, Pembiayaan Musyarakah Dan Sewa Ijarah Terhadap Profitabilitas. Vol. 3 No. 1.

Putra, P. \& Hasanah, M. (2018). Pengaruh Pembiayaan Mudharabah, Murabahah Dan Ijarah Terhadap Profitablilitas 4 Bank Umum Syariah Periode 2013-2016. Jurnal Organisasi Dan Manajemen. Vol 14. No. 2.

Romdhoni, H.A. Yozika, Al, F. (2018). Pengaruh Pembiayaan Mudharabah, Musyarakah Dan Ijarah Terhadap Profitabilitas Bank Muamalat Indonesia. Jurnal Ilmiah Ekonomi Islam. Vol. 4. No. 3.

Sugiyono. (2017), "Metode Penelitian Kuantitatif, Kualitatif, dan R\&D". Bandung. Alfabeta.

Sulistiyo Hari dkk. (2020). Teknik menelusiri dan memahami artikel ilmiah du jurnal nasional dan internasional. Karawang. Cv Absolute Media.

V, Wiratna, S. (2016). "Kupas Tuntas Penelitian Akuntansi dengan SPSS". Yogyakarta. Pustaka Baru Press.

Wiroso. (2011). Akuntansi Transaksi Syariah. Jakarta. Ikatan Akuntansi Indonesia 